\title{
KANDUNGAN KLOROFIL DALUGHA (Cyrtosperma merkusii (Hassk.) Scott) PADA HUTAN RAWA PASANG SURUT DI DESA LAINE, PULAU SANGIHE
}

\author{
CHLOROPHYLL CONTENT OF DALUGHA (Cyrtosperma merkusii (Hassk.) Scott) IN \\ TIDAL SWAMP FOREST OF LAINE VILLAGE, SANGIHE ISLAND
}

\author{
Semuel P. Ratag, Euis F.S. Pangemanan, dan Johny S. Tasirin*) \\ *)Program Studi IImu Kehutanan, Fakultas Pertanian Unsrat Manado, 95115
}

\begin{abstract}
This article is to present the adaptation capacity of Dalugha (giant taro, Cyrtosperma merkusii) indicated by chlorophyll contents at a number of places in Laine Village, Sangihe Island. The study is related to the development of Dalugha as an alternative food plant and its adaptation to the inundated brackish water as a result of raising sea water surface on climate change. The aim of the study is to analyze the differences in chlorophyll contents of inundated and non inundated brackish water conditions in a tree shaded and non shaded conditions. The method is observational where plant responses are observed at the variation created by natural caused. The result showed cthat Dalugha chlorophyll content was influenced by tree shading but it is not influenced by inundation of brackish water.
\end{abstract}

Keywords: dalugha, chlorophyll, tidal swamp forest

\begin{abstract}
ABSTRAK
Artikel ini menggambarkan tentang adaptasi tanaman Dalugha yang diindikasikan oleh kandungan klorofil pada beberapa tempat tumbuh di Desa Laine, Pulau Sangihe. Penelitian ini berhubungan dengan pengembangan tanaman Dalugha sebagai alternatif tanaman pangan dan adaptasinya terhadap kondisi tergenang air payau yang berkaitan dengan kenaikan permukaan laut sebagai dampak perubahan iklim.Penelitian ini bertujuan untuk menganalisis perbedaan kandungan klorofil pada kondisi tempat tumbuh tergenang-tidak tergenang air payau dan kondisi tempat tumbuh terbuka-ternaungi pepohonan.Metode yang digunakan adalah metode observasional dimana respon tanaman diamati pada suatu kisaran kondisi yang diadakan oleh alam. Kandungan klorofil diamati dengan metode pengukuran absorban ekstrak daun tanaman menggunakan spektrofotometer.Hasil penelitian menunjukkan bahwa kandungan klorofil tanaman Dalugha dipengaruhi oleh kondisi tempat tumbuh terbuka-ternaungi pepohonan dan tidak dipengaruhi oleh kondisi tergenang-tidak tergenang air payau. Kata kunci: dalugha, klorofil, hutan rawa pasang surut
\end{abstract}




\section{PENDAHULUAN}

Dalugha (Cyrtosperma merkusii (Hassk.) Scott) adalah nama lokal untuk tanaman talas rawa raksasa (giant swamp taro) di Pulau Sangihe. Nama ilmiah lainnya/sinonim adalah $C$. lasoides, $C$. edule, and C. chamissonis (Flach and Rumawas, 1996). Satu-satunya jenis dalam genus Cyrtosperma yang dapat dimakan adalah Dalugha (Hay, 1990). Tanaman ini tergolong famili Araceae yang diduga tanaman asli Indonesia yang telah tersebar di Phillipina. Papua New Guinea, dan beberapa pulau di Kepulauan Pasifik (Plucknett, 1977), dapat hidup pada lahan basah (wetland) yang digenangi atau jenuh air sepanjang hari maupun temporer dengan salinitas berkisar 0,59 hingga $1,991 \mathrm{ppt}$ dan $\mathrm{pH}$ air genangan berkisar 6,9 hingga 9,8 (Ratag, 2013).

Habitat yang menjadi fokus penelitian ini adalah lahan basah yang digolongkan dalam hutan rawa pasang surut air tawar (tidal freshwater swamp forest), terletak di daerah pesisir pantai dan merupakan habitat tanaman Dalugha (Cyrtosperma merkusii (Hassk.)Schott) di Desa Laine, Kecamatan Manganitu Selatan.

Sistem klasifikasi tipe-tipe lahan basah, eksosistem hutan rawa pasang surut termasuk dalam tipe lahan basah pesisir dan lautan (kategori I), yaitu Intertidal Forested Wetlands (Ramsar Convention Secretariat, 2006). Ancaman terhadap lahan basah telah meningkat dimana lebih dari setengah luas lahan basah yang ada di dunia telah berkurang (Turpie, et al., 2010). Informasi tentang lahan basah, terutama rawa pasang surut air tawar meliputi komponen fisik dan biologis menjadi hal yang menarik karena masih kurang diteliti (Anderson dan Lockaby, 2007; Conner, et al., 2007).

Adanya Dalugha di Pulau Sangihe telah dilaporkan oleh van Dinter pada tahun 1899 dan Vorderman pada tahun 1899 (Henley, 2005). Tanaman ini telah menjadi salah satu tanaman pangan yang penting bagi masyarakat di Pulau Sangihe dan sekitarnya dengan merebus umbinya dengan air atau digoreng menjadi kue yang biasanya disebut ketang-ketang. Umbi Dalugha dapat dijadikan tepung sebagai bahan dasar maupun tambahan untuk pembuatan kue brownies, balapis, onde-onde (Ratag, 2013).

Dalugha yang bisa bertumbuh di lahan basah pada daerah pesisir memiliki potensi untuk dikembangkan dalam hubungannya dengan upaya peningkatan ketersediaan pangan dan mengantisipasi dampak perubahan iklim, khususnya kenaikan permukaan laut. Tasirin dan Ratag (2016) menyatakan bahwa Dalugha biasanya tumbuh di lahan basah, toleran salinitas, toleran naungan, dan toleran pada lahan dengan kandungan hara rendah.

Pengembangan Dalugha membutuhkan informasi tentang adaptasi tanaman ini dalam kondisi tempat tumbuh tergenang-iidak tergenang air payau serta tempat tumbuh terbuka-ternaung. Salah satu indikator yang berhubungan dengan adaptasi tanaman adalah kandungan klorofil.

Respon pertumbuhan tanaman terhadap berbagai tempat tumbuh dapat berbeda-beda antara satu jenis dengan jenis lainnya. Adaptasi setiap jenis tanaman terhadap tempat tumbuh dapat menghasilkan pertumbuhan dan hasil tanaman yang berbeda-beda pula. Ada tanaman tertentu akan menunjukkan pertumbuhan dan hasil yang lebih baik bila ditumbuhkan pada kondisi ternaung dibandingkan tempat terbuka, demikian pula sebaliknya. Hal ini disebabkan karena kemampuan tanaman untuk beradaptasi terhadap lingkungan ditentukan oleh sifat genetik tanaman (Mohr dan Schopfer, 1995).

Karakteristik biologis Dalugha berkaitan dengan daya adaptasinya terhadap kompleksitas variasi habitat di ekosistem rawa pasang surut masih kurang diteliti, termasuk informasi tentang kandungan klorofil Dalugha pada kondisi tempat tumbuh air payau dan variasi terbuka-ternaung relatif masih sangat sedikit. Tujuan penelitian ini adalah untuk menganalisis perbedaan kandungan klorofil pada kondisi tempat tumbuh tergenang-tidak tergenang air payau dan kondisi tempat terbukaternaungi pepohonan. Hasil penelitian ini dapat menjadi referensi bagi peneliti lainnya tentang adaptasi Dalugha pada berbagai kondisi tempat tumbuh berkaitan dengan upaya pembudidayaan dan upaya konservasi tanaman tersebut. 


\section{METODE PENELITIAN}

Penelitian dilaksanakan di hutan rawa pasang surut Desa Laine, Kecamatan Manganitu Selatan, Kabupaten Kepulauan Sangihe dan Laboratorium IImu Tanaman, Fakultas Pertanian Universitas Sam Ratulangi Manado. Penelitian berlangsung selama sebulan, yaitu Bulan November 2012.

Bahan yang digunakan, yaitu daun tanaman Dalugha, aseton $80 \%$. Alat yang digunakan adalah parang, gunting, pisau cutter, wadah plastik, spidol, label, timbangan digital, spektrofotometer Biochrom Libra S12, mortar, erlenmeyer, gelas ukur, beker gelas, pipet, kertas tissue, dan kertas saring Whatman 42.

Penelitian menggunakan metode pendekatan observasional dimana respon organisme diamati pada suatu kisaran kondisi yang diadakan oleh alam (Ludwig and Reynolds, 1988). Sampel daun diperoleh dari tanaman Dalugha yang bertumbuh pada empat kondisi yang yang dipilih secara sengaja, yaitu: 1. Tergenang air payau dan ternaungi pepohonan (L1-N), 2. Tergenang air payau dan terbuka (L1-T), 3.Tidak tergenang air payau dan ternaungi pepohonan (L2-N), dan 4.Tidak tergenang air payau dan terbuka (L2-T).

\section{Prosedur Penelitian}

Langkah-langkah yang dilakukan untuk pengambilan sampel daun adalah: 1) Mengambil sampel daun dewasa berdasarkan empat kondisi tempat tumbuh tanaman. Sampel daun di setiap lokasi diambil dari tiga individu tanaman sebagai ulangan; 2) Masukkan sampel daun dalam wadah plastik dan memberikan label kode sampel; 3) Menyimpan sampel-sampel daun dalam tas pendingin; 4) Membawa ke laboratorium untuk analisis kandungan klorofil.

Kegiatan untuk menganalisis kandungan klorofil di laboratorium dilakukan dengan langkahlangkah sebagai berikut: 1) Sampel daun segar tanpa tulang daun dipotong kecil, diambil secara komposit sebanyak 1 gram kemudian dimasukkan ke dalam mortar. Potongan daun tersebut dihancurkan menggunakan mortar sampai halus atau berbentuk pasta; 2) Tambahkan aseton $80 \%$ secukup- nya hingga jaringan menjadi homogen lalu diaduk, kemudian masukkan ke dalam labu ukur menggunakan corong yang telah dilapisi kertas saring; 3 ) Tambahkan aseton $80 \%$ ke dalam labu ukur sehingga mencapai $50 \mathrm{ml}$; 4) Untuk pengenceran, ekstrak klorofil dalam labu ukur diambil sebanyak $1,0 \mathrm{ml}$ dan dipindahkan ke labu ukur berukuran 10 $\mathrm{ml}$ dan ditambahkan aseton $80 \%$ sampai volume mencapai $10 \mathrm{ml}$; 5) Ekstrak klorofil yang telah diencerkan tersebut diukur absorbannya menggunakan spektrofotometer dengan panjang gelombang $645 \mathrm{~nm}$ dan $663 \mathrm{~nm}$. Penentuan kadar klorofil a dan b menggunakan metode perhitungan yang dilakukan Yoshida et al. (1976), yaitu:

Klorofil a $=(0,0127 D 663-0,00269 D 645)$

Klorofil $b=(0,0229 D 645-0,00468 D 663)$

Total klorofil $=$ klorofil $a+$ klorofil $b$

Untuk jumlah klorofil per bobot daun segar dihitung dengan persamaan:

Klorofil $a=(0,0127$ D663 - 0,00269 D645) $\times 1 /$ ws $x$ $v s / 1000 \times F P$

Klorofil $b=(0,0229 D 645-0,00468$ D663) $\times 1 /$ ws $x$ $v s / 1000 \times F P$

dimana :

D $663=$ absorbansi pada $\lambda 663 \mathrm{~nm}$

D $645=$ absorbansi pada $\lambda 645 \mathrm{~nm}$

vs $=$ volume sampel $(\mathrm{ml})=50 \mathrm{ml}$

ws $=$ berat sampel $(\mathrm{g})=1 \mathrm{~g}$

$\mathrm{FP}=$ faktor pengenceran $=10 \mathrm{x}$.

Setiap daun individu tanaman yang dijadikan sampel pengukuran klorofil, diambil tiga buah sampel (3 ulangan) berukuran $5 \times 5 \mathrm{~cm}$.Ketiga sampel diambil pada bagian bawah helai daun, tengah, dan ujung daun.

\section{Variabel Pengamatan}

Variabel pengamatan terdiri dari: 1. Klorofil a, 2. Klorofil b, dan 3. Total klorofil berdasarkan empat kondisi tempat tumbuh tanaman Dalugha, yaitu tergenang air payau dan ternaungi pepohonan (L1-N), tergenang air payau dan terbuka (L1-T), tidak tergenang air payau dan ternaungi pepohonan (L2-N), dan tidak tergenang air payau dan terbuka (L2-T). 


\section{Analisis Data}

Data dianalisis menggunakan sidik ragam (ANOVA). Bila hasil analisis sidik ragam menunjukkan perbedaan yang nyata maka dilanjutkan dengan Uji BNT 0,05.

\section{HASIL DAN PEMBAHASAN}

\section{Kandungan Klorofil a}

Klorofil a yang terkandung dalam daun Dalugha yang bertumbuh pada empat kondisi tempat tumbuh, kombinasi dari variasi kondisi cahaya terbuka-ternaung dan kondisi permukaan tanah tergenang-tidak tergenang air payau menunjukkan adanya perbedaan. Tabel 1 memperlihatkan bahwa kandungan klorofil a tertinggi diperoleh dari daun tanaman Dalugha yang bertumbuh pada kondisi tergenang air payau dan ternaungi pepohonan (L1$\mathrm{N})$ dengan nilai rataan $3,842 \mathrm{mg} / \mathrm{l}$ dannilai terendah pada kondisi tergenang air payau dan terbuka (L1T) dengan nilai rataan 2,096 mg/l.

Hasil analisis statistik menunjukkan bahwa tempat tumbuh tergenang air payau dan ternaung (L1-N) dan tempat tumbuh tidak tergenang air payau dan ternaung (L2-N) berbeda nyata dengan tempat tumbuh tidak tergenang air payau dan terbuka (L2-T) dan tempat tumbuh tergenang air payau dan terbuka (L1-T). Pada kondisi terbuka (T), tidak ada perbedaan antara kondisi tergenang (L1) dan tidak tergenang air payau (L2). Sama halnya dengan pada kondisi ternaung (N), tidak ada perbedaan antara kondisi tergenang (L1) dengan tidak tergenang (L2). Pada kondisi tempat tumbuh tergenang air payau (L1), nilai klorofil a di tempat ternaung $(\mathrm{N})$ dengan nilai $3,842 \mathrm{mg} / \mathrm{lberbeda}$ nyata dan lebih tinggi daripada tempat terbuka ( $\mathrm{T}$ ) dengan nilai 2,096 $\mathrm{mg} / \mathrm{l}$. Kandungan klorofil a pada kondisi tidak tergenang air payau (L2) dan ternaung (N) dengan nilai $3,735 \mathrm{mg} / \mathrm{l}$ berbeda nyata dan lebih tinggi daripada tempat terbuka $(\mathrm{T})$ dengan nilai 2,311 $\mathrm{mg} / \mathrm{l}$. Berdasarkan hasil analisis statistik dapat disimpulkan bahwa perbedaan kandungan klorofil a dipengaruhi oleh kondisi cahaya terbuka dan ternaung dan tidak dipengaruhi oleh kondisi tergenang dan tidak tergenang air payau.

\section{Kandungan Klorofil $\boldsymbol{b}$}

Klorofil $b$ yang terkandung dalam daun Dalugha yang bertumbuh pada empat kondisi tempat tumbuh, kombinasi dari variasi kondisi cahaya terbuka-ternaung dan kondisi permukaan tanah tergenang-tidak tergenang air payau menunjukkan adanya perbedaan. Tabel 2 memperlihatkan bahwa kandungan klorofil $b$ tertinggi diperoleh dari daun tanaman Dalugha yang bertumbuh pada kondisi tergenang air payau dan ternaungi pepohonan ( $\mathrm{L} 1-\mathrm{N})$ dengan nilai rataan $1,898 \mathrm{mg} / \mathrm{l}$ dan nilai terendah pada kondisi tidak tergenang air payau dan terbuka (L2-T) dengan nilai rataan $1,029 \mathrm{mg} / \mathrm{l}$.

Hasil analisis statistik menunjukkan bahwa tempat tumbuh tergenang air payau dan ternaung (L1-N) dan tempat tumbuh tidak tergenang air payau dan ternaung (L2-N) berbeda nyata dengan tempat tumbuh tidak tergenang air payau dan terbuka (L2-T) dan tergenang air payau dan terbuka (L1-T).Pada kondisi terbuka ( $\mathrm{T})$, tidak ada perbedaan antara kondisi tergenang (L1) dan tidak tergenang air payau (L2). Sama halnya dengan pada kondisi ternaung $(\mathrm{N})$, tidak ada perbedaan antara kondisi tergenang (L1) dengan tidak tergenang (L2).

Hasil analisis statistik menunjukkan bahwa pada kondisi tempat tumbuh tergenang air payau (L1), nilai klorofil $b$ di tempat ternaung (N) dengan nilai $1,898 \mathrm{mg} / \mathrm{l}$ berbeda nyata dan lebih tinggi daripada tempat terbuka $(T)$ dengan nilai 1,141 $\mathrm{mg} / \mathrm{l}$. Kandungan klorofil a pada kondisi tidak tergenang air payau (L2) dan ternaung $(\mathrm{N})$ dengan nilai $1,683 \mathrm{mg} / \mathrm{l}$ berbeda nyata dan lebih tinggi daripada tempat terbuka (T) dengan nilai 1,029 $\mathrm{mg} / \mathrm{l}$. Berdasarkan hasil analisis statistik dapat disimpulkan bahwa perbedaan kandungan klorofil a dipengaruhi oleh kondisi cahaya terbuka dan ternaung dan tidak dipengaruhi oleh kondisi tergenang dan tidak tergenang air payau. 
Tabel 1. Kandungan Klorofil a

(Table 1. Content of Chlorophyll a)

\begin{tabular}{ccc}
\hline Tempat Tumbuh & Rataan Klorofil a $(\mathrm{mg} / \mathrm{l})$ & Notasi $\left.^{*}\right)$ \\
\hline L1-T & 2,096 & $\mathrm{a}$ \\
L2-T & 2,311 & $\mathrm{a}$ \\
L2-N & 3,735 & $\mathrm{~b}$ \\
L1-N & 3,842 & $\mathrm{~b}$ \\
\hline
\end{tabular}

Ket.: *Angka yang diikuti oleh huruf yang sama menunjukkan tidak berbeda nyata $(B N T 5 \%=0,404)$

Tabel 2. Kandungan Klorofil $b$

(Table 2. Content of Chlorophyll b)

\begin{tabular}{ccc}
\hline Tempat Tumbuh & Rataan Klorofil $b(\mathrm{mg} / \mathrm{l})$ & Notasi $\left.^{*}\right)$ \\
\hline L2-T & 1.029 & $\mathrm{a}$ \\
L1-T & 1.141 & $\mathrm{a}$ \\
L2-N & 1.683 & $\mathrm{~b}$ \\
L1-N & 1.898 & $\mathrm{c}$ \\
\hline
\end{tabular}

Ket.: *Angka yang diikuti oleh huruf yang sama menunjukkan tidak berbeda nyata $(B N T 5 \%=0,161)$

\section{Kandungan Total Klorofil}

Total klorofil adalah penjumlahan dari klorofil a dan klorofil $b$. Tabel 3 memperlihatkan bahwa kandungan total klorofil tertinggi diperoleh dari daun tanaman Dalugha yang bertumbuh pada kondisi tergenang air payau dan ternaungi pepohonan (L1-N) dengan nilai rataan $5,740 \mathrm{mg} / \mathrm{l}$ dan nilai terendah pada kondisi tidak tergenang air payau dan terbuka (L2-T) dengan nilai rataan 3,236 $\mathrm{mg} / \mathrm{l}$.

Hasil analisis statistik menunjukkan bahwa pada kondisi tempat tumbuh tergenang air payau (L1), nilai total klorofil di tempat ternaung (N) dengan nilai $5,740 \mathrm{mg} / \mathrm{l}$ berbeda nyata dan lebih tinggi daripada tempat terbuka $(\mathrm{T})$ dengan nilai 3,236 mg/l. Kandungan total klorofil pada kondisi tidak tergenang air payau (L2) dan ternaung (N) dengan nilai $5,419 \mathrm{mg} / \mathrm{l}$ berbeda nyata dan lebih tinggi daripada tempat terbuka (T) dengan nilai 3,236 mg/l. Berdasarkan hasil analisis statistik dapat disimpulkan bahwa perbedaan kandungan total klorofil dipengaruhi oleh kondisi cahaya terbuka dan ternaung dan tidak dipengaruhi oleh kondisi tergenang dan tidak tergenang air payau.

Data yang diperoleh menunjukkan adaptasi Dalugha pada kondisi tergenang-tidak tergenang dan kondisi cahaya ternaung-terbuka.
Pengamatan kandungan klorofil dalam organ daun Dalugha menunjukkan bahwa kandungan klorofil dipengaruhi oleh kondisi cahaya ternaung dan terbuka. Pada kondisi cahaya ternaung kandungan klorofil a dan b meningkat. Perubahan karakteristik daun pada kondisi ternaung adalah adalah daun menjadi lebar dan tipis (Salisbury dan Ross, 1992).

Setiap jenis tanaman memiliki adaptasi terhadap kondisi tempat tumbuh yang berbeda-beda. Dalam kondisi ternaung, pertumbuhan dan hasil tanaman tertentu akan menunjukkan pertumbuhan dan hasil yang lebih baik bila ditumbuhkan pada kondisi ternaung dibandingkan tempat terbuka. Hal ini disebabkan karena kemampuan tanaman untuk beradaptasi terhadap lingkungan ditentukan oleh sifat genetik tanaman (Mohr dan Schopfer, 1995).

Hasil penelitian Ratag (2013) tentang kandungan klorofil tanaman Dalugha di Desa Pokol, Kecamatan Tamako, Kabupaten Kepulauan Sangihe menunjukkan hal yang sama, yakni kandungan klorofil tanaman Dalugha tidak dipengaruhi oleh kondisi tergenang-tidak tergenang air payau, melainkan dipengaruhi oleh kondisi terbuka dan ternaungi pepohonan. Berdasarkan hasil penelitian ini, Dalugha termasuk tanaman yang mampu beradaptasi dan tumbuh baik pada kondisi ternaung. 
Tabel 3. Kandungan Total Klorofil

(Table 3. Content of Chlorophyll Total)

\begin{tabular}{ccc}
\hline Tempat Tumbuh & Rataan Total Klorofil $(\mathrm{mg} / \mathrm{ll})$ & Notasi $\left.^{*}\right)$ \\
\hline L1-T & 3.236 & $\mathrm{a}$ \\
L2-T & 3.340 & $\mathrm{a}$ \\
L2-N & 5.419 & $\mathrm{~b}$ \\
L1-N & 5.740 & $\mathrm{~b}$ \\
\hline
\end{tabular}

Ket.: *Angka yang diikuti oleh huruf yang sama menunjukkan tidak berbeda nyata $(B N T 5 \%=0,483)$

Pertumbuhan tanaman pada kondisi ternaung berarti intensitas cahaya yang diterima oleh daun rendah (Gardner et al., 2003) menyebabkan laju fotosintesis dan sintesis karbohidrat menurun (Chowdury, et al., 1994). Untuk meningkatkan laju fotosintesis dan sintesis karbohidrat pada kondisi intensitas cahaya rendah maka daun tanaman Dalugha menjadi lebih lebar dan terjadi peningkatan kandungan klorofil a dan $b$ agar cahaya yang ditangkap dan ditransfer ke pusat reaksi fotosintesis semakin banyak. Taiz dan Zeiger (1991) menyatakan bahwa klorofil $b$ berfungsi untuk menangkap dan mengumpulkan cahaya untuk ditransfer dan digunakan pada pusat reaksi. Pusat reaksi terjadi pada klorofil a dimana energi cahaya akan diubah menjadi energi kimia yang digunakan dalam proses fotosintesis. Peningkatan klorofil $b$ berkaitan dengan peningkatan protein klorofil sehingga menaikkan efisiensi antena fotosintetik (Hidema, et al., 1992). Selanjutnya dikatakan bahwa tanaman menyesuaikan diri pada kondisi cahaya rendah dicirikan dengan membesarnya antena untuk fotosistem II. Membesarnya antena untuk fotosistem II akan menaikkan pemanenan cahaya. Johnston dan Onwueme (1996) menyatakan bahwa peningkatan klorofil $a$ dan $b$ pada tanaman talas (Colocasia esculenta) merupakan kemampuan tanaman tersebut untuk tumbuh di bawah kondisi cahaya yang rendah. Peningkatan klorofil $a$ dan $b$ merupakan salah satu bentuk mekanisme toleransi tanaman terhadap naungan (Sahardi, 2000).

\section{KESIMPULAN}

Adaptasi tanaman Dalugha yang dilihat dari perbedaan kandungan klorofil pada berbagai tempat tumbuh menunjukkan bahwa kondisi ter- buka-ternaung pepohonan mempengaruhi kandungan klorofil a, klorofil b, dan total klorofil, sedangkan tempat tumbuh tergenang-tidak tergenang air payau tidak mempengaruhi.Kandungan klorofil a tertinggi diperoleh dari tanaman Dalugha yang bertumbuh pada kondisi tergenang air payau dan ternaung dengan nilai rataan $3,842 \mathrm{mg} / \mathrm{l}$. Kandungan klorofil $b$ tertinggi diperoleh dari tanaman Dalugha yang bertumbuh pada kondisi tergenang air payau dan ternaung dengan nilai rataan 1,898 $\mathrm{mg} / \mathrm{l}$, dan kandungan total klorofil tertinggi diperoleh dari tanaman Dalugha yang bertumbuh pada kondisi tergenang air payau dan ternaungidengan nilai rataan $5,740 \mathrm{mg} / \mathrm{l}$.

\section{DAFTAR PUSTAKA}

Anderson, C.J. and B. G. Lockaby. 2007. Soil and biogeochemistry of tidal freshwater forested wetlands. In: States, W. H. Conner, T. W. Doyle, and K. W. Krauss (Eds.). 2007 Ecology of tidal freshwater forest wetland of the southeastern United pp. 65-88.

Chowdury, P.K., M. Thangaraj and Jayapragasm. 1994. Biochemical Changes in Low Irradiance Tolerant and Succeptible Rice Cultivars. Biol. Plantarum 36 (2): 237-242.

Conner, W.H., C.T. Hackney, K.W. Krauss, and J.W. Day Jr. 2007. Tidal freshwater forested wetlands: Future research needs and an overview of restoration. In: W. $\mathrm{H}$. Conner, T. W. Doyle, and K. W. Krauss (Eds.). 2007. Ecology of tidal freshwater forest wetland of the southeastern United States, pp. 461-488. 
Flach, M. and F. Rumawas. 1996. Plants Yielding Non-seed Carbohydrates. Plant Res. South East Asia (PROSEA), vol. 9, 1996.

Gardner, F.P., R.B. Pearce, and R.L. Mitchell.2003 Physiology of Crop Plants. lowa State University, lowa.

Hay, A. 1990. Aroids of Papua New Guinea. Christensen Research Institute, Port Moresby, Papua New Guinea.

Henley, D. 2005. Fertility, Food, and Fever: Population, Economy and Environment in North and Central Sulawesi 1600-1930. KITLV Press. Netherlands.

Hidema, J., A. Makino, Y. Kurita, T. Mae, and K. Ohjima. 1992. Changes in the Level of Chlorophyll and Light-harvesting Chlorophyll a/b Protein PS II in Rice Leaves Agent Under Different Irradiances from Full Expansion Through Senescens. Plant Cell Physiology 33(8): 1209-1214.

Johnston, M. and J.C. Onwueme. 1998. Effect of Shade on Photoshyntetic Pigments in the Tropical Root Crops: Yam, Taro, Tannia, Cassava and Sweet Potato. Exp. Agric. 34: 301-312.

Ludwig, J.A dan J.F. Reynolds. 1988. Statistical Ecology. John Wiley and Sons. New York.

Mohr, H and P. Schopfer. 1995. Plant Physiology. Terjemahan: L. Gudrun and D.W. Lawlor. Springer-Verlag. Heidelberg, Berlin.

Plucknett, D.L. 1977. Giant swamp taro, a littleknown Asian-Pacific food crop. In: Cock J., R. Maclntyre, and M. Graham (eds.), Proceedings of the Fourth Symposium of the International Society for Tropical Root Crops Held at CIAT, Cali, Colombia, 1-7 August 1976, page 36-40. IDRC080e.IDRC, Ottawa, Canada.
Ratag, S.P. 2013. Analisis Habitat Tanaman Dalugha (Cyrtosperma merkusii (Hassk.) Schott) Pada Hutan Rawa Pasang-Surut Pulau Sangihe. Disertasi. Fakultas Pertanian, Program Pasca Sarjana, Universitas Brawijaya, Malang.

Ramsar Convention Secretariat. 2006. The Ramsar Convention Manual: a Guide to the Convention on Wetlands (Ramsar, Iran, 1971), $4^{\text {th }}$ ed. Ramsar Convention Secretariat, Gland, Switzerland.

Salisbury, F.B. and C.W. Ross. 1992. Plant Physiology. $4^{\text {th }}$ edition. Wadsworth Publishing Company, Belmont, California.

Sahardi. 2000. Studi Karakteristik Anatomi dan Morfologi serta Pewarisan Sifat Toleransi Terhadap Naungan Pada Padi Gogo (Oryza sativaL.). Disertasi. Institut Pertanian Bogor, Bogor.

Taiz, L. and E. Zeiger. 2010. Plant Physiology. $5^{\text {th }}$ edition. Sinauer Associates Inc., Sunderland.

Tasirin, J.S. dan S.P. Ratag, 2016. Biogeografi Daluga untuk Prospek Ketahanan Pangan Nasional. Makalah Seminar Nasional Pertanian: Pengembangan Sumber Daya Pertanian untuk Menunjang Kemandirian Pangan. Seminar dalam rangka Dies Natalis ke-56 Fakultas Pertanian Unsrat di Hotel Aryaduta, 26 April 2016, Manado.

Turpie, J., K. Lannas, N. Scovronick and A. Louw. 2010. Wetland Ecosystems Services and Their Evaluation: A Review of Current Understanding and Practice. Water Research Commission Report.

Yoshida, S., D.A. Forno, J.H. Cock, and K.A. Gomez. 1976. Laboratory manual for physiological studies of rice. The International Rice Research Institute.Los Banos, Laguna, Philippines. 
